\title{
Shame and Alcoholism in Paula Hawkins's The Girl on the Train
}

\author{
Maysaa H. Jaber \\ Psychological Research Center \\ Baghdad, Iraq \\ Email: maysajaber@gmail.com
}

Received: 8/21/2021 Accepted: 10/2/2021 Published: 10/24/2021

\begin{abstract}
The aim of this article is to showcase the connection between the portrayal of shame and alcohol addiction, on the one hand, and the mystery of murder and violence against women, on the other, in Paula Hawkins's thriller The Girl on the Train (2015). This article argues that Hawkins's book uses the thriller formula to reveal the links between gender and violence by delving into the vulnerability, suffering and resilience of the female characters through the stories of alcoholic troubled protagonist, Rachael Watson and the mystery of Megan Hipwell's murder.
\end{abstract}

Keywords: alcohol addiction, The Girl on the Train, Paula Hawkins, mystery, shame, thrillers, Shame Resilience Theory, violence against women

Cite as: Jaber, M. H. (2021). Shame and Alcoholism in Paula Hawkins's The Girl on the Train . Arab World English Journal for Translation \& Literary Studies 5 (4) 60-71.

DOI: http://dx.doi.org/10.24093/awejtls/vol5no4.5 


\section{Introduction}

Paula Hawkins's The Girl on the Train (2015) introduces complex intersections between the psychology of shame and alcoholism in women on the one hand, and the mystery of murder and the violence against women, on the other. Through an alcoholic disturbed protagonist, the book delves into the depth of suffering and vulnerability of Rachael Watson and her journey with shame, guilt, and alcohol addiction. At the same time, Hawkins dissects violence against women through the murder mystery at the heart of the book. This article argues that shame and alcoholism are not only connected in the way they are portrayed in the novel but they are also gendered; gender roles and dynamics are key to the presentation of shame and alcoholism in the female characters. Moreover, by using the psychological thriller as a medium, Hawkins conveys the complexity of these interconnections shedding light on women's positionality within this genre. The Girl on the Train tells the story of Rachael, a woman who struggles with alcoholism after she lost everything; her husband when he left her for another woman, her house, and her job. She rides the train every day from the suburb of Ashbury where she has a rented room in her friend's house to Central London where she used to work. She roams aimlessly watching people on her train rides including Tom and his new wife, Anna, and the woman who is murdered, Megan Hipwell. The novel focuses on Rachael's mixed-up emotions of guilt and shame due to her blackouts after excessive drinking and her tumultuous relationship with her ex-husband, Tom. However, it is revealed at the end of the book that Tom is the one who killed Megan and he also manipulated and abused Rachael all along. The novel ends with a violent confrontation between Rachael and Tom where he confesses that he killed Megan, then he attacks Rachael who kills him in self-defense.

The Girl on the Train seems to suggest that female brokenness and marginalization are part of a bigger project of abuse, trauma, and violence. Hawkins creates a complex flawed protagonist and unreliable narrator. ${ }^{1}$ Her psychological makeup is marked with suffering on both physical and psychological levels. She feels that her body betrayed her as a woman for she could not have children when she was married to Tom. Then, there is her sense of low self-esteem and feelings of worthlessness that are part of her cycle of shame and alcohol. Rachael is shown to have lost control over many aspects of her life. Her alcoholism is the late stage of a longer complicated history as far as her relationship with Tom is concerned. There are layers and complexities to Rachael's characterization, perhaps a mystery that parallels that of the murder of Megan. The novel peels these layers one by one, and it is not until the revelation of Tom as the murderer that everything about Rachael falls into place; her shame, addiction to alcohol, and memory gaps are all tied to the abuse she endured at the hands of Tom while she could not remember any of the things he said or did to her. All this left wounds and scars on Rachael and resulted in serious consequences and damage to her psyche.

Rachael's shame seems to be at the core of all her problems and the key to the conclusion of the book. Her shame is shaped by her low self-esteem and is intensified by her alcohol addiction. She seems to be trapped in a cycle of loss of control, guilt and shame which is exacerbated by her alcohol. She is "powerless" and she "lost control over everything, even the places in [her] head" (Hawkins, 2015, p.9). Part of this cycle is Rachael's holding on to the past and her refusal to cast any doubt on Tom. Rachael also struggles with alcoholic amnesia; she does 
not have any recollection of what happened or what she said or did after her heavy drinking episodes. She seems tormented by the gaps in her memory which adds to her shame. Ultimately, the novel links Rachael's inner turmoil to the crime at the center of the events in a thriller that positions the voices of women as the main vehicle to tell the story.

\section{The Broken Drunken Woman in The Girl in the Train}

The novel starts with an unknown voice narrating the "remembrance" of a woman buried underneath a tree near the train tracks. It establishes the mystery from the very start of the novelthe murder of a woman and the centrality of women to the plot. By focusing on this anonymous woman, the book creates the mystery, and it sets the diary-like narration of the three female characters in the book: Rachael, Megan, and Anna, Tom's second wife. What ties the story together is the disappearance and murder of Megan with the reader following the investigation trying to uncover the murderer as well as tracing the links between these female narrators. The novel is structured as a diary of entries written by the three women. Each one tells her own story which allows a perspective into these women's lives and slowly reveals the meeting points between them with Tom as the common link. It also offers three perspectives to the murder of Megan and to the history and life experiences of these women. There are invisible linkages that are only revealed through the women's voices and narration, particularly the story of Rachael and her thoughts and feelings on her train rides.

Rachael's story is the most compelling and primary one amongst the three women, and her perspective is valuable not only to the action of the plot but also to the gender dynamics painted in this book. She is the central focus of all the action and the one who resolves the mystery of Megan's murder. From the beginning, it is evident that she is a woman suffering from grief, loneliness, and alcoholism. The story invests in Rachael's deep-seated problems and struggles and unravels her pain and suffering in almost a graphic detail. However, Rachael also plays the role of the detective, albeit using immature and even reckless ways, to solve the case of Megan's disappearance. The main plot and Rachael's investigation revolves around the fact that she, while under the influence of alcohol, unknowingly watched Megan with Tom the night of her disappearance but Rachael could not remember. Moreover, Rachael also fits the bill of the victim, though she also implicates herself in the action. At the end of the book when it is revealed that Tom is the villain, Rachael's role can be seen with a new angle, more like a victim to Tom's manipulations than merely as an alcoholic broken woman, although she also commits murder in self-defense.

Rachael's double roles in the book both as a suspect and a victim, as a person of interest in the investigation and the one who is doing the investigation, set up the dichotomies at the heart of the story. Rachael has also drunken and sober sides which are in conflict with one another. It seems that Rachael's characterization is circular until the end when she finally breaks free from her own shame. She finds her strength when she stops drinking. The narrative also construes the implications of Rachael as a suspect. She herself, out of shame, suspects her involvement in Megan's disappearance and because she does not remember what happened, her suspicions become even more pronounced. When the police start to question Rachael and come to her housemate's house, Rachael makes the link between her lost memory and the possibility that she 
might have been involved, she admits, "I black out and I can't remember where I've been or what I've done... it's so hard to feel responsible for something you don't remember" (Hawkins, 2015, p.189). She is entrapped within her own psyche and her shame and self-hate. Hawkins also plays with the perceptions around people and life experiences especially these of women. Throughout the book, Tom and Anna seem to be the victims of Rachael's relentless harassment. Rachael constantly calls Tom and leaves angry messages and visits his house while drunk. Yet the ending shows a different, perhaps an opposite picture of what really happened exposing another face for Tom. The ending also displays the duality of the victim/perpetrator, and the fact that what seems to be true on the surface does not always represent reality or truth.

The book thus focuses on Rachael's unreliability, her memory gaps, her lies and her internal thought processes as far as her shame is concerned. The story situates Rachael's memories about what she witnessed with Megan against her alcoholism and her feelings of shame. Rachael's character is thus based on unreliability, not merely as an unreliable narrator and witness but also as one who lies and is not always trustworthy. She admits "lying was easier" (Hawkins, 2015, p. 121), which is mostly due to her drinking and blackouts. So, the text builds the case for Rachael's unreliability through her memory gaps and amnesia as well as establishing the tension between lies and truth. There is lack of confidence on Rachael's part about what she did and what she remembers; she gives an explanation to her predisposition to be unreliable: "What I know from my own observations, I don't really know" (Hawkins, 2015, p. 107) ${ }^{2}$ Also, Rachael acknowledges about the day Megan's disappearance that:

Something happened, something bad. There was an argument. Voices were raised. Fists? I don't know, I don't remember. I went to the pub, I got on the train, I was at the station, I was on the street. Blenheim Road. (Hawkins, 2015, p.39)

Yet this unreliability proves to be the key to solve the crime. Rachael becomes obsessed with solving the case, following clues, and trying to remember: "I am ashamed now of the secret thoughts I had. Megan is not a mystery to be solved ... She is not a cipher. She is real" (Hawkins, 2015, p.106). But once Rachael refills in the gaps in her memory about what happened that night, and faces Tom, it eventually becomes the point when she stops drinking and starts to gain back control over her life. By emphasizing the role of Rachael as a vulnerable troubled immature detective invested in solving Megan's murder, the novel displays the inner workings of women's psychology of shame by trying to fill in the gaps in her memory and fighting her addiction to alcohol.

As "the master emotion of everyday life" (Scheff, 2003, p.239), shame is the dominant theme in The Girl in the Train. Shame causes emotional and social distress for Rachael who struggles to lead a normal and healthy life and has a serious alcohol addiction. She is trapped in a cycle that is hard to break. While there are many scholars who examined the concept of shame, Brene Brown's theory about shame (Shame Resilience Theory (SRT)) is illuminating and will be adopted here to read Hawkins's text and her female protagonist ${ }^{3}$ In "Shame Resilience Theory: A Grounded Theory Study on Women and Shame," Brown defines shame as an "intensely painful 
feeling or experience of believing we are flawed and therefore unworthy of acceptance and belonging" (2006, p. 45). Brown also talks about shame as a construct that is structured around ideas and behaviors of the self. However, there is also a social dominion to experiencing shame in how it relates to relationships and connections especially for women (2006, p. 45). Shame, according to Brown's theorization, is understood according to three main domains that encompass the emotions of shame: feeling "trapped, powerless and isolated" (2006, p. 45). Feeling trapped refers to "expectations and options" where the person feels there are unrealistic expectations with limited options. Feeling powerless, on the other hand, is related to the properties of "consciousness, choice, and change" with the person facing shame often feels unable to change or have any power over what he/she experiences. While feeling isolated is the product of feeling both trapped and powerless, it entails a sense of a disconnect with people and environment. These three concepts, namely entrapment, powerlessness and isolation, are better understood when the intersection between them is considered; the "intricate weaving" between them is what makes shame complex. Brown's theory also offers a scheme for the "main concerns of women experiencing shame and identifies the strategies and processes women find effective in developing shame resilience" ( Brown, 2006, p. 45). Rachael's experience with shame will be analyzed through these three domains. She indeed feels trapped, powerless and isolated, and these feelings for the female protagonist have myriad effects on the plot and her interactions with other characters, especially in regard to the theme of violence against women.

It is noteworthy to mention that shame is misunderstood and misconstrued even by scholars. It is often confused with low self-esteem or guilt, ${ }^{4}$ and it is also connected to a variety of mental health and social concerns including depression, domestic abuse, suicide, and addiction. However, one of the ways to read shame is through the lens of a "web" as "layered, expectations that are, at the core, products of rigid socio-cultural expectations" (Brown, 2006, p. 46). These expectations, especially for women, rely on what their identities "are supposed to be" based on gender, race, class, age as well as their roles, for example, women as mothers, employees, partners, etc. (Brown, 2006, 46). This applies to Rachael particularly in relation to her infertility and her complicated relationship to her ex-husband. Shame in women discloses the "far reaching" expectations that are formulated by relationships and life experiences. Miller and Stiver also argue that women rely on an "inner sense of connection to others" which is essential to their development, while women's sense of worth is "grounded in the ability to make and maintain relationships" (1997, p.16). This pertains to Rachael who has lost her self-esteem when she lost her husband and her friends. When the book starts, she is lonely and separated from others with no one to rely on or trust. Rachael's alcoholism, which takes a major part of the plot, seems to be only a symptom of her problems and her inner turmoil. We learn that Rachael's turmoil is defined primarily by her shame.

The link between shame and alcoholism is also important to consider here. Generally, there are scholars who associate addiction with the difficult emotions and the inability to cope and function (Meehan, et al,1996, p. 125). The role of shame has been investigated as the etiology of psychopathology. For example, O'Connor and Weiss (1993) argue that the emotional distress caused by addition is closely related to intense emotions such as shame, with anger often happening secondarily in response to these emotions. Moreover, the stigma placed on women 
who have addiction problems is greater than men, and usually "shame is heavier for women" ( O'Connor , et al, 1994, p. 503). Rachael is presented to have an array of difficult emotions and her way to cope is excessive drinking which led her into a deeper state of shame and depression. ${ }^{5}$ Indeed the plot of The Girl in the Train offers a dive to Rachael's feelings of shame and belittlement and provides a glimpse into the psychology of a woman with deep pain, she describes her pain "I want to drag knives over my skin, just to feel something other than shame, but I'm not even brave enough to do that" (Hawkins, 2015, p.105). When it comes to Rachael's shame, there is a physical aspect as she feels inadequate as far as her appearance is concerned. The narrative focuses on Rachael's self-image, her own perception of herself is one of the reasons behind her feelings of shame. She has a low self-esteem, and it is related to her appearance and attraction: "I am not the girl I used to be. I am no longer desirable, I'm off-putting in some way" (Hawkins, 2015 , p. 11). She is also aware of the changes she experienced after her divorce both physically and psychologically: "it's not just that I've put on weight, or that my face is puffy from the drinking and the lack of sleep; it's as if people can see the damage written all over me" (Hawkins, 2015, p.11). Here she equates her less than desirable physical appearance to the "damage" she acknowledges. More importantly, there is a deep-seated reason behind her shame, her infertility. This is at the crux of her feelings of humiliation and inadequacy: "I' $m$ not beautiful and I can't have kids, so what does that make me? Worthless" (Hawkins, 2015, p.79). Loss and grief are central to Rachael's shame, she is grieving the children she could have never had. Her inability to have children is a loss she mourns and then this loss is compounded by the loses of her husband, job, friends, and the life that she left behind. This eventually leads her to drowning in shame and drinking.

The theme of motherhood is tightly associated with those of shame in the book. One can argue that The Girl on the Train is a story about loss - the loss of love, family and self and the consequences of these losses and the turmoil they cause on the fragile psyche of a woman. Rachael describes the inescapability of being affected by her childlessness: "The thing about being barren is that you're not allowed to get away from it" (Hawkins, 2015, p. 78). She has a vivid image of what constitutes her perfect family when she was married, so when she could not get pregnant, she fell apart. Part of this image is constructed by expectations of people around her, "My friends were having children ... I was asked about it all the time ... When was it going to be my turn? (Hawkins, 2015, p.78). Rachael's loss of her ability to be a mother is the point when she starts to lose control of herself and her life. Indeed, the main source of Rachael's pain and shame is when she came to realize that she would not have a perfect family: "our childlessness became an acceptable topic of Sunday-lunch conversation, not just between Tom and me, but more generally ... failure cloaked me like a mantle, it overwhelmed me, dragged me under, and I gave up hope" (Hawkins, 2015, p.78) ${ }^{6}$ She started to descend into the cycle of guilt, drinking and blackouts. The narrative also poses Rachael's dilemma against other women especially Anna who is married to Tom and shares a baby with him. Rachael is jealous of Anna not only as Tom's wife but also as a new mother to a baby Rachael herself could not have. Hawkins puts the odds against Rachael by positioning her against other women and injecting her in the puzzle of Megan and making her the key to answer the questions regarding the mystery. 
During her train rides, Rachael watches and creates stories about people she follows closely. As a voyeur, Rachael watches the scenery and the houses like she watches a film on a screen, but she also keeps an eye on Tom and his wife and another couple she names "Jason" and "Jess," who turn out to be Megan and her husband, Scott. Rachael seems obsessed with Megan and her husband thinking of them as a happy couple weaving stories about them that are only the product of her imagination. These train rides where Rachael is constantly shown to be obsessing about other people mirror her loneliness and her isolation. It is noteworthy to mention that the novel is structured around train commuting from and into London between the suburbs and the city, and from work and home. It is presented like diary entries with the main narrator, Rachael, going through day-to-day experiences. However, we discover that these trains rides are purposeless as Rachael, mostly drunk, does not have a job to go to. These trips are nothing more than an attempt at denial on the part of Rachael to keep pretending that her life is still as it was. London is also a central trope in the book. The novel can be considered as a "comment on London's centrality for its writers, those who invent and investigate the cracks that the city opens up in our lives" (Mehmi, 2015, p.112). The book thus uncovers the cracks in Rachael's psyche and her train rides serve like a stream of consciousness for her incoherent drunken thoughts and emotions. From the start, we are introduced to Rachael as a woman with active imagination, a detail that is significant to her character as alcoholic with blackouts and memory gaps. It also sets the ground for Rachael's interest in the story of the disappearance of Megan that Rachael insists on solving and indeed it turns out she is the key to the solution and identification of the murderer. Megan also has her own story and secrets. When we first see her in the novel, she expresses nostalgia for the place she used to live and a job she used to have. From the start, we see her dissatisfaction and a sense of sadness to be further explored later in the narrative, she states, "I can't risk looking backwards, it's always a bad idea" (Hawkins, 2015, p. 18). Later, we learn that Megan has also a traumatic experience as far as motherhood is concerned. Megan caused her baby's death when she fell asleep in the bathtub and the baby drowned as a result. She is constantly sleepless and suffers from nightmares, she describes her state: "I woke feverish, panicky. Guilty. I do feel guilty. Just not guilty enough" (Hawkins, 2015, p. 61). The text illustrates that at the root of Megan's troubles and her restlessness is guilt and shame. Hawkins does not reveal the secret of the death of her baby until the end when we discover that Megan's life, which she herself narrates is the opposite of what Rachael imagines in her train rides. This disillusionment of women's stories in this book reveals Hawkins's interest in the psychology of women's inner turmoil of shame and the engagement in self-destructive behavior. With her guilt and shame, Megan is not only restless but she engages with Tom in an affair that finally leads to her murder when she gets pregnant with his child and threatens him to expose the affair.

Motherhood here functions as a connecting link between Rachael and Megan. The novel shows the dynamics of motherhood, on the one hand, and guilt and shame, on the other especially in relation to violence against women. As both struggle with grief over children, Rachael and Megan somehow are brought together in feelings of guilt and shame. Although Megan does not drink, she suffers from feelings of "hollowness." She believes in the inevitability of her suffering: "I'm starting to believe that there isn't anything you can do to fix it" and describes the inner wounds as "holes" that are "permanent. You have to grow around them, like tree roots around concrete; you mold yourself through the gaps" (Hawkins, 2015, p.94). There is also another aspect 
in Hawkins's novel that illustrates the isolation and alienation her female characters suffer from, which are the core elements in Brown's theory of shame mentioned above. Both Rachael and Megan are victims to Tom, but they also feel alienated and misunderstood in addition to being trapped and isolated. The sense of unbelonging, evident in both Rachael and Megan, is part of their trauma and shame.

Rachael seems to be in a vicious circle of isolation and loneliness, drinking, feelings of shame that lead to more drinking and blackouts. Rachael is presented as an outsider; she is situated on the margins of life, a woman who is not part of any social or family circle, a woman riding purposelessly on the train. She is all alone, and she only has her train rides and alcohol after she lost everything. She also has two sides; like a "female Jekyll and Hyde, Rachael's two sidesthe sober and the drunken - struggle with each other" (Mehmi, 2015, p.113). The effects of Rachael's drinking are crucial mainly because it affects her credibility and reliability as a witness, immature detective, and narrator. The blackouts and the memory gaps are at the heart of the book's mystery are also central to the characterization of Rachael. Through Rachael, Hawkins illustrates the dark psyche of a woman whose struggles and problems are relatable but also intriguing. Brown's theorization of three concepts relevant to shame comes to mind; entrapment, powerlessness and isolation; all these are part and parcel of Rachael's suffering "I felt me lonelier, because no one likes being around a drunk. I lost and I drank and I drank and I lost" (Hawkins, 2015, p. 79).

So, the novel establishes a connection between memory, shame, and crime resolution in relation to the female characters. Rachael's shame and the resulting alcoholism are tied to her memory and offers an "affective spatiality" as the "means" to solve the mystery of Megan when Rachael succeeds in recovering her memories by "an emotional exploration of the spaces of the crime(s)" (Rodríguez-González, 2017, p. 117). Once Rachael remembers what Tom did, not only to Megan but to her when they were married, the crime is resolved, and her shame no longer takes complete control over her. Gaps in Rachael's memory and the blackouts that she suffers from with her excessive drinking are thematically central to her characterization and to the plot itself, "I close my eyes and let the darkness grow and spread until it morphs from a feeling of sadness into something worse: a memory, a flashback" (Hawkins, 2015, p.13) ${ }^{7}$ Her memory gaps are thus intertwined with her feelings of sadness and shame. She always feels humiliated by her memory loss, and she emphasizes that she has to apologize for something she does not remember "I learned that when you wake up like that, you don't ask what happened, you just say that you're sorry: you're sorry for what you did and who you are" (Hawkins, 2015, p.261). The fragmentation in Rachael's memories, the lost parts, the gaps are all indicative of the narrative technique that Hawkins uses to disclose the narrative voice of Rachael. At the same time, these gaps, once filled, represent the solution not only to the crime but also to Rachael's shame.

Rachael tries to reconstruct the crime narrative and fill the gaps of the parts she does not remember, blackouts "happen ... Total black; hours lost, never to be retrieved" (Hawkins, 2015, p.67). She even uses paper scraps to create a trajectory of what happened the night Megan disappeared. The events take a turn when Rachael sees a therapist in her effort to remember but her therapy sessions reveal to her and to the reader that some of the gaps of her memories, the 
blackouts have been exploited by Tom who shaped many of her distorted memories and used them to manipulate Rachael. Tom's exploitation of Rachael's blackouts "determines Rachael's sense of identity as 'othered"' (Flores-Quesada, 2019, p.159). Rachael is desperate to construct a coherent narrative and by so doing, she reconstructs the conceptualizations of not only what happened with Megan but also of the reality of her own life experiences. Through the gaps, she pieces together a solution to the crime and at the same time her story with Tom. As Giovanelli ( 2018) suggests:

Hawkins' representation of Rachel's mind is a fundamental thematic and stylistic concern in the novel. The Girl on the Train depends to a great extent on Rachel and, crucially, how she is presented. Her blackouts effectively create the mystery: if she could remember then there would be no puzzle to solve. (p.49)

This novel is about the mystery and the puzzle, a whodunit with the primary question of who killed Megan. However, it is not structured like a classic whodunit that often has a traditional detective and an investigation. Instead, the medium used here is the thriller. Thrillers rely on suspense, excitement, the element of surprise, tension, and anticipation. ${ }^{8}$ Situating the female characters, especially Rachael, in the middle of a disappearance/murder story serves the plot and highlights the positioning of shame and alcoholism as keys to resolve the mystery. In what Suzi Feay describes the book as "amnesia thriller," Rachael seems lost at times, but more often she is struggling with her baggage and pain. She tends to undermine and underestimate herself, not only in terms of her blackouts, but her shame seems to weigh her down to the point that she loses her confidence and self-belief: "I never learn. I wake with a crushing sensation of wrongness, of shame, and I know immediately that I've done something stupid" (Hawkins, 2015, p.101). That is, the narrative from the start emphasizes Rachael's feelings of inadequacy and shame, hence it discloses another facet of the effects of violence against women. So when Rachael comes to terms with the roots of her issues- the abuse she endured at the hand of Tom while she is drunk, she realizes that he is "a master at it, making me feel as though everything is my fault, making me feel worthless" (Hawkins, 2015, p.315). Once she comes to this realization of the violence she encountered, although she could not recall it all, she resolves her feelings of shame and succeeds in pointing to Tom as the main perpetrator.

The text sets up an emotional attachment with Rachael but it is an attachment nothing short of ambivalent. While sympathizing with Rachael's suffering, there is also doubt about her credibility and truthfulness. Her unreliability also complicates the investigation process. For example, when Rachael goes to the police to tell them about what she witnessed, detective Riley doubts her story and makes it clear that she does not believe her. Detective Riley tells Rachael: "you are unwilling to move on, that you refuse to accept that your ex has a new family" (Hawkins, 2015, p.83). This is a statement that sums up Rachael's state of being "stuck" and being trapped in the past, but she is also trapped in her negative emotions, in her "web of shame." In this thriller formula which drives the question of who killed Megan after her body is found, Rachael's story is set against a detective who belittles her word and testimony. Rachael's memory seems to be the problem and the solution. 
The moment Rachael starts to remember and fill in the gaps in her memories, it is also the moment that she starts to change. She starts to gain confidence and have more faith in herself, and this is also when she decides to get sober. When Rachael remembers what Tom did to Megan, she has a new perspective not only to the traumatic memories of what she witnessed that night but also to her past and her marriage to Tom. The novel outlines the journey of a woman who apparently was the victim of the psychological (and physical) abuse of her ex-husband all masked by her alcoholism and her lost memories. It is also revealed that Tom is a liar and unfaithful husband. Once Rachael realizes who Tom really was, she breaks free from her shame and guilt and gains agency not only to solve the crime but also to change and move forward in life.

One of the crucial questions that the book brings forth is that of female agency and empowerment - does Rachael find her voice and her agency by the end of the novel and why? Hawkins's book is about a vulnerable protagonist who has a long history of being entrapped and powerless. Yet by the end Rachael confronts Tom in a dramatic encounter when he confesses to murdering Megan and taunts and attacks Rachael when she finally attacks back "I swing. I jam the vicious twist of the corkscrew into his neck"(Hawkins, 2015, p. 317). Rachael ultimately succeeds in turning her shame and pain into resilience. She embarks on a journey of healing. Once Rachael realizes that she has been the victim and that she had been exploited by Tom, she starts to see the past with a new lens; she regains some of her lost confidence. The first step for her is sobriety and the book ends with her taking another train ride away from her previous life: "Eventually, I suppose, the nightmares will stop... I have to get up early tomorrow morning to catch the train" (Hawkins, 2015, p. 323). Hawkins ends her book on a positive note, women's resilience.

\section{Conclusion}

The Girl on the Train can be thought of as having feminist undertones as it is concerned with stories of troubled broken women who are judged and dismissed by people and society at large. Using unreliable female narrators, the book goes into the depth of the vulnerability and suffering of women. It shows the effects of trauma on women and their entrapment in the cycle of alcohol and shame. While Hawkins exposes the serotypes of women and the (mis)conceptions around them, her book is not a feminist book per se. Hawkins presents marginalized women with motherhood at the heart of this feminist critique. The narrative also shows the different sides to Rachael, as a victim but also a liar, as a desperate unemployed woman who harasses her exhusband and his new wife but also as one who was a victim of his abuse. It is a brave representation of the complexity of Rachael with all her various sides and facets. Through an imperfect, almost unflattering character of Rachael, The Girl on the Train succeeds in showing the vulnerability and marginalization of women with the different complex facets of victimhood and agency.

\footnotetext{
About the Author:

Maysaa Jaber is a lecturer at the Psychological Research Center and teaches different modules on literature to undergraduate and postgraduate students at the University of Baghdad. She published with Palgrave, Cambridge Scholars, The Canadian Review of American Studies, Rowman \& Littlefield Publishers, and Critique: Studies in Contemporary Fiction. Her first
} 
manuscript The Criminal Femmes Fatales in American Hardboiled Crime Fiction came out in 2016 with Palgrave Macmillan, Springer. ORCID ID: https://orcid.org/0000-0003-4840-6598

\section{Notes}

1. The Girl in the Train has received negative criticism from some critics. For example, Jacqueline Rose (2015) suggests that Hawkins's book is full of "hatred women... women [who] lack intelligence" (p. 26). Rose also states that Hawkins's characterization of her female protagonist is not successful; and that the author goes against the feminist agenda by turning "abuse of women into a treat" (p. 26).

2. For more on unreliability in The Girl in the Train, see Grebeniuk (2018).

3. For more on the concept of shame, see Balcom, Lee and Tager (1995), Dearing, Stuewig, and Tangney (2005), and Lewis (1971).

4. According to Edith Lisansky Gomberg, shame is related to "humiliation, with the awareness of others that one is disgraced," while guilt involves responsibility and culpability. So guilt translates into "I did wrong and I should make amends," but people often internalize shame (1988, p. 139). See also Dearing, Stuewig and Tangney (2005) for the differences between shame and guilt.

5. For more on the relation between shame and alcoholism, see Potter-Efron and Potter-

6. For more on the significance of motherhood in The Girl on the Train, see Björkén-Nyberg (2018).

7. According to Goodwin (1971), there are two types of blackouts. The first is the experience in which the person registers "lost time," but the blackout episode has a beginning and an ending, and it is rarely followed by a return of memories. The second type, however, refers to the state when a person experiencing blackouts forgets the events after the episode with no immediate recollections but the "eventual recall, however hazy, was the rule" (p. 1665). For more on blackouts, see Rose and Grant (2010).

8. For more on thrillers, see Palmer (1984) and Glover (2003).

\section{References}

Balcom, D., Lee, R. G., \& Tager, J. (1995). The systemic treatment of shame in couples. Journal of Marital and Family Therapy, 21(1), 55-65.

Björkén-Nyberg, C. (2018). Vocalising motherhood: The metaphorical conceptualisation of voice in listener responses to The girl on the train by Paula Hawkins. International Journal of Language Studies, 12(4), 1-28.

Brown, B. (2006). Shame resilience theory: A grounded theory study on women and shame. Families in Society, 87(1), 43-52.

Dearing, R. L., Stuewig, J., \& Tangney, J. P. (2005). On the importance of distinguishing shame from guilt: Relations to problematic alcohol and drug use. Addictive behaviors, 30(7), 1392-1404.

Feay, S (2015). "The Girl on the Train by Paula Hawkins Review- A skillful memory loss Thriller." The Gradian.

Flores-Quesada, M. M. (2019). (Vulner)ability: An Analysis of Women in Paula Hawkins's Novels. Revista Clepsydra 18, 153-170. 
Giovanelli, M. (2018). 'Something happened, something bad': Blackouts, uncertainties and event construal in The Girl on the Train. Language and Literature, 27(1), 38-51.

Glover, D. (2003). The Thriller. In Martin Priestman (Ed.) The Cambridge companion to crime fiction (pp.135-153).Cambridge University Press.

Goodwin, D. W. (1971). Two Species of Alcoholic" Blackout". American Journal of Psychiatry, 127(12), 1665-1670.

Grebeniuk, T. (2018). Narrative Unreliability in Paula Hawkins' The Girl on the Train as a Strategy of Reader Immersion. American \& British Studies Annual 11, 36-48.

Hawkins, Paula (2015). The Girl on the Train. Riverhead Books.

Lewis, H. B. (1971). Shame and Guilt in Neurosis. New York, International Universities Press.

Lisansky Gomberg, E. S. (1988). Shame and guilt issues among women alcoholics. Alcoholism treatment quarterly, 4(2), 139-155.

Meehan, W., O'Connor, L. E., Berry, J. W., Weiss, J., \& Acampora, A. (1996). Guilt, shame, and depression in clients in recovery from addiction. Journal of psychoactive drugs, 28(2), 125-134.

Mehmi, S. (2015). Review of The Girl on the Train. The Literary London Journal. 12(1-2), 112115.

Miller, J. B., and Stiver, I. P. (1997) The healing connection: How women form relationships in therapy and life. Beacon Press.

O'Connor, L. E., Berry, J. W., Inaba, D., Weiss, J., \& Morrison, A. (1994). Shame, guilt, and depression in men and women in recovery from addiction. Journal of substance abuse treatment, 11(6), 503-510.

O'Connor, L. E., \& Weiss, J. (1993). Individual psychotherapy for addicted clients: An application of control mastery theory. Journal of Psychoactive Drugs, 25(4), 283-291.

Palmer, J. (1984) Thrillers. In Christopher Pawling ( Ed.) Popular fiction and social change (pp.76-98). Palgrave.

Potter-Efron, R., \& Potter-Efron, P. (2013). The treatment of shame and guilt in alcoholism counseling. Routledge.

Rodríguez-González, C. (2017). Geographies of Fear in the Domestic Noir: Paula Hawkins's The Girl on the Train. Miscelánea: A Journal of English and American Studies, 56, 109-127.

Rose, J. (2015). Corkscrew in the neck. London Review of Books, 37(17), 25-26.

Rose, M. E., \& Grant, J. E. (2010). Alcohol-induced blackout: phenomenology, biological basis, and gender differences. Journal of addiction medicine, 4(2), 61-73.

Scheff, T. J. (2003). Shame in self and society. Symbolic interaction, 26(2), 239-262.

Arab World English Journal for Translation \& Literary Studies 